\title{
Impact of management practices on construction productivity in Indian building construction projects: an empirical study ${ }^{1}$
}

DOI 10.2478/otmcj-2021-0007

Received: December 26, 2019; Accepted: March 20, 2020

\begin{abstract}
The objective of this study is to analyse the impact of management practices on the productivity of building construction projects in India. The methodology adopted for this study is to identify and analyse the management practice attributes from the literature review and expert focus group interviews. The identified attributes were analysed and priorities using relative weight were given by the respondents. The collected data were further analysed using SPSS 21 software. The quantitative research methodology was adopted to analyse the collected data and the following tools and techniques were applied to the data: reliability analysis to check the consistency of data collected for this study and relative importance index (RII) to prioritise and rank the attributes based on the weighted average score given by the respondents. The findings of this study concluded that coordination between all stakeholders, ability to handle the crisis by the project managers, social skills of key team managers, timely payment of completed works and design capability and frequent design changes are the most significant attributes of management practice, affecting construction productivity and having a rating on the RII of 0.91, 0.90, $0.88,0.87$ and 0.87 .
\end{abstract}

Keywords: management practice, project management, construction productivity, construction management, built environment, Indian construction industry

\footnotetext{
${ }^{1}$ This paper is an extended version of the paper accepted and presented at CCC2019.
}

*Corresponding author: Saurav Dixit, RICS School of Built Environment, Amity University, Noida, Uttar Pradesh, India.

E-mail: sauravarambol@gmail.com

\section{Introduction}

Indian economy is one of the fastest growing economies in the world with an average growth rate of $6-7 \%$. The construction industry in India is the second largest employer after the agriculture industry and it contributes about $8-10 \%$ on an average to the economy. It is growing further as the rate of urbanisation followed by green and brownfield developments will increase (Banawi and Bilec 2014). The construction industry in India is unorganised, and the majority of the workforce employed is uneducated and ignorant to sustainable practices and is driven only by the motive of commercial viability ignoring every other factors such as quality, sustainability, health and safety and operability (Jamil and Fathi 2016; Neelamkavil 2009; Dixit and Sharma 2019). Majority of the construction projects in India is suffering from a delay in construction, over budget, quality and low productivity. Low construction productivity is one of the major issues that impact on the performance of construction projects to get completed on time and within budget (Banawi and Bilec 2014; Khodeir and Othman 2016; Jiang et al. 2016; Ajala et al. 2017; Ameh et al. 2010; Xu et al. 2018; Björnfot and Sardén 2006).

Indian construction industry is very diverse, fragmented and apparently unorganised. The skilled and quality workforce has always been one of the most critical issues for the industry. Due to the unique nature of work, coordination, timely delivery and quality have always been a subject to ponder. The productivity in the construction industry has been studied and documented all around the world and it has the advantage of over 40 years of research that have developed models, identified the factors affecting productivity, studies at the industry level, the study of equipment and technology to enhance productivity and techniques to measure 
and improve construction productivity (Zhang and Fan 2013; Ma et al. 2015; Barlow 2009; Sweis et al. 2016; Molavi and Barral 2016; Howell 1999; Castellani et al. 2018) which results in enhancing construction productivity and labour productivity. Various research have been done to find out several factors that influence the construction productivity and the findings include the business culture, education level, tools and technologies used, values and ethics of the people and workers involved, politics, local laws and regulations governing the project, HR policies of the organisation, importance given to the employee, religion of the people, their cultures, languages, etc. (Al-Tabtabai et al. 1997; Ocampo and Clark 2015; Alves et al. 2012).

\section{Literature review}

Productivity could be measured at different levels, but there are three main productivity measures: metronomic, case-by-case and pricing studies. The financial wealth of nations is determined by their productivity growth (Fulford and Standing 2014; Tsehayae and Fayek 2016; Mani et al. 2017; Grau et al. 2009; Kaming et al. 1997). The countries experienced higher productivity growth as a result of the increase in the average wage of workers which contributes to the profits and tax revenue of the countries. The trend is not consistent over time due to a number of reasons, such as unplanned training sessions, consistency of skills development courses and a decrease in the number of participants (Oglesby et al. 1989; Lee et al. 2007; Moselhi and Khan 2010; Ameh and Osegbo 2011; Mahamid 2013; Santosh and Apte 2014; Alazzaz and Whyte 2015; Chalker and Loosemore 2016; Ma and Liu 2018). Construction productivity has been an area of research interest since the last 4-5 decades.

It is very difficult to set up a benchmark for productivity and standard productivity measures to increase output. The projects are usually planned and calculated based on the historical data and experience. It is important to take into account the differentiator and the variables that we need for the project and the different factors (Neelamkavil 2009; Burgess et al. 2017).

The various factors include:

1. Size of the project undertaken

2. Project design complexities

3. Wearing site conditions such as soil drainage topography
4. Weather conditions such as rain, summer, winter, etc.

5. Seasons changes

6. Manpower and labour conditions such as skilled and unskilled labour

7. Government or regulatory requirements

8. Material source supply and IDs

9. Complexity to transport and logistics

10. Design changes (Chalker and Loosemore 2016; Wang et al. 2013; Doloi et al. 2012; Teizer et al. 2013; Jarkas and Bitar 2012)

Labour productivity or yield per hour is the best among other measures of construction productivity. The final objective of each sector in the country, including construction, is to increase productivity. Macroeconomics information indicates that the overall productivity of work in the construction sector decreased during the period 1979-1998. Productivity information of the construction sector in the United States from 1979 to 1998 determined its legitimacy and reliability (Poirier et al. 2015). To ensure the suitability of the BIM usage process, it is crucial for associations hoping to change to BIM to have the capacity to manage and measure these advantages. This article showed the discoveries of an activity study of a project with a small mechanical temporary worker who was investigating the effect of BIM on the productivity of work on an expansive business project (Kwon et al. 2014). The findings showed the assumption that Australian subcontractors are large contract workers only. Productivity multipliers for construction productivity are regularly evaluated on a specially designed premise, subject to the task attributes. Safa et al. (2016) studied the use of automated rebar mounting machines to improve the productivity of construction work and reduce the likelihood of accidents involving rebar yard workers. The author concluded that work is concentrated and costly, with a high learning curve that limits speciality capabilities to a lot of field involvement in construction. Research and construction controls for rebar tie have been sensibly constrained. This study showed that the programmed rebar mounting machine could lower the learning curve, reduce the preparation time and limit the overtime. The results of this study showed that the programmed rebar mounting machine can possibly spare time, money and economic liabilities without gambling labour productivity. The analysis of a complex subject is very difficult to develop and it requires a lot of imagination (Table 1 ). 
Tab. 1: Selected variables for the current study

\begin{tabular}{|c|c|}
\hline Selected variables for the current study & References \\
\hline $\begin{array}{l}\text { Urgency emphasised by the owner while issuing the tender, customer/ } \\
\text { client satisfaction, inadequate project formulation in the beginning }\end{array}$ & $\begin{array}{l}\text { Chancellor and Abbott (2015), Aziz and Hafez (2013) and } \\
\text { Dixit (2018) }\end{array}$ \\
\hline $\begin{array}{l}\text { Scope clarity of the project, the exceptional difference between client } \\
\text { and architect }\end{array}$ & $\begin{array}{l}\text { Dixit (2018), Sezer and Bröchner (2014) and Dixit et al. } \\
\text { (2019a) }\end{array}$ \\
\hline $\begin{array}{l}\text { Coordination between all stakeholders, contractual disputes, design } \\
\text { capability and frequent design changes }\end{array}$ & $\begin{array}{l}\text { Jarkas et al. (2012), Afifi et al. (2016) and Lim and Alum } \\
\text { (1995) }\end{array}$ \\
\hline $\begin{array}{l}\text { Developing and maintaining a short and informal line of communication, } \\
\text { human resource and a labour strike, ability to delegate authority, rework }\end{array}$ & $\begin{array}{l}\text { Sezer and Bröchner (2014), Dixit et al. (2019a) and Jarkas } \\
\text { et al. (2012) }\end{array}$ \\
\hline $\begin{array}{l}\text { Timely payment of completed works, site clearance/availability, cost, } \\
\text { quality, supply chain }\end{array}$ & $\begin{array}{l}\text { Afifi et al. (2016), Lim and Alum (1995) and Assefa Tsehayae } \\
\text { et al. (2016) }\end{array}$ \\
\hline $\begin{array}{l}\text { Social skills of key team managers, interpersonal skills, climate condi- } \\
\text { tions, social environment, political and economic environments }\end{array}$ & $\begin{array}{l}\text { Assefa Tsehayae et al. (2016), Ma and Liu (2014) and Abdul } \\
\text { Kadir et al. (2005) }\end{array}$ \\
\hline $\begin{array}{l}\text { Willingness to adopt change, claim geniuses, conflict of interests among } \\
\text { team members, ability to handle the crisis by the project managers, } \\
\text { availability of training and development for enhancing skills }\end{array}$ & $\begin{array}{l}\text { Abdul Kadir et al. (2005), Ma et al. (2016) and Ok and Sinha } \\
\text { (2006) }\end{array}$ \\
\hline
\end{tabular}

\section{Research methodology and data analysis}

The methodology adopted for this study is to identify and analyse the management practice attributes from the literature review and expert focus group interviews. The identified attributes were analysed and priorities using relative weight were given by the respondents. The data were collected using a structured questionnaire on pan India basis, and both online and offline modes of data collection were used. The collected data were further analysed using SPSS 21 software. Quantitative research methodology was adopted to analyse the collected data and the following tools and techniques were applied to the data: reliability analysis to check the consistency of data collected for this study and relative importance index (RII) to priorities and rank the attributes on the basis of weighted average score given by the respondents were performed on the data collected.

\subsection{Data collection}

The questionnaire floated to the professionals associated and working in the Indian construction industry and 105 valid responses were received. The data were collected using a structured questionnaire survey consisting of the 19 identified attributes from the literature. The received responses were analysed using SPSS 21 software and excel spreadsheets.

\subsubsection{Respondents profile}

The questionnaire data collection was adopted because of the scarcity of the secondary data available on the research topic in Indian scenario. The respondents selected for this study were directly associated with the Indian construction industry such as architects, clients, consultants, contractors, academicians and other stakeholders. The respondents were selected irrespective of their gender, demography and the type of projects to give an equal change to the population. The finding of this study concluded that the respondents represented the industry and also different roles and responsibilities. The respondents were selected randomly and the questionnaire was sent over mail to the respondents for seeking information on this study. The respondents were followed by three reminders to submit their responses. A total of 108 responses were received out of which three were discarded because of incomplete information. Finally, 105 valid responses were considered for this study. The similar approach for collecting primary data using questionnaire survey was recommended and adopted by few expert groups in previous studies.

\subsubsection{Position/designation of the respondents}

Of note, $35 \%$ of the respondents were working at the operational level, followed by middle management, top management, others (academician, NGOs and other groups) and advisor/consultant level having the percentage shares of $27,19,11$ and $8 \%$, respectively. If we club the top 
management and middle management, then the percentage of the respondents would become $46 \%$ (Figure 1).

\subsubsection{Years of respondents' experience}

The respondents were having a rich years of experience in assessing their material quality and their hard work when choosing the study sample, which enabled the respondents to provide a simple and accurate description of the characteristics that affect the construction efficiency and demonstrate the reliability and accuracy of the collected data (value of Cronbach's alpha for the current study is 0.87) (Figure 2).

\subsubsection{Reliability analysis of the sample}

To assess the internal consistency of the survey instrument, the Cronbach's alpha test was carried out. The research discussed the precision and consistency of the collection of specimens. As a rule, the precision and consistency of the collected data were measured at a minimum of 0.5. The experiment showed a value of Cronbach's alpha of 0.87 for the current study, making the results perfect for analysis (Dixit et al. 2019b).

\section{Designation of the respondents}

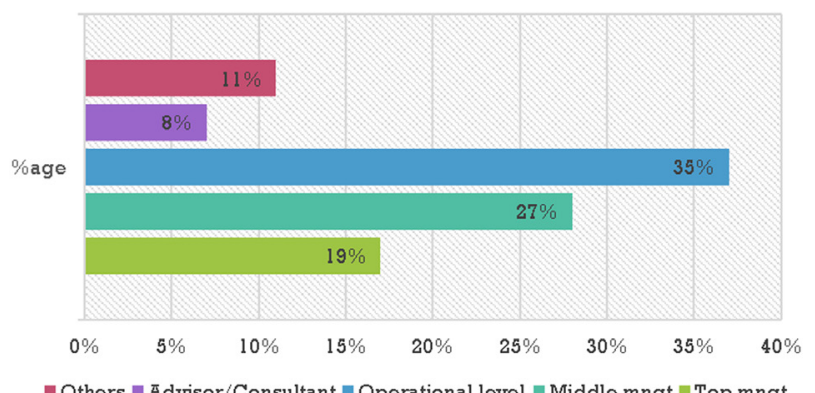

Fig. 1: Position/designation of the respondents.

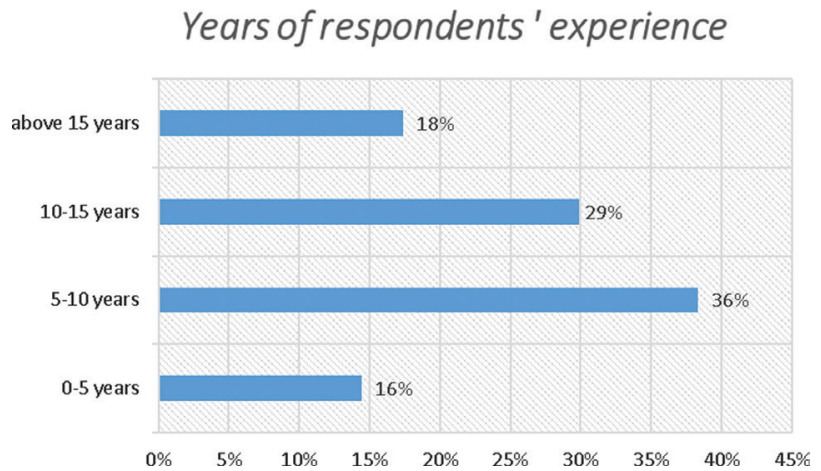

Fig. 2: Years of respondents' experience.

\subsubsection{RII of the attributes in this study}

The contribution of each variable to the overall significant attributes of management practices affecting construction productivity in the Indian construction industry was determined using the relative significance index measured by the respondent using the equation for its criticality, and the qualitative effects are shown in the Table 3. The ranking of different attributes from the point of view of the contractor, developers and consultant was assessed using the RII equation (Dixit 2018; Dixit et al. 2017).

The responses received were compiled in the Excel datasheet and evaluated using the SPSS21 package. The RII was carried out to define the importance of attributes and was accompanied by a reliability test to validate the accuracy of the results obtained (0.87; Table 2$)$.

$$
\mathrm{RII}=\frac{\sum_{r=1}^{5} r{ }^{\star} \mathbf{n}_{r}}{5 \mathbf{N}} .
$$

\subsubsection{The most significant attributes of management practices affecting construction productivity in the Indian construction industry}

The most significant attributes of management practices affecting construction productivity in Indian construction industry are coordination between all stakeholders, ability to handle the crisis by the project managers, social skills of key team managers, timely payment of completed works and design capability and frequent design changes having a rating on the RII of $0.91,0.90,0.88,0.87$ and 0.87 , respectively (Table 3 ). Coordination between stakeholders and social skills are the main significant attributes in the success of any projects as reported by Hughes and Thorpe (2014) and Iyer and Jha (2005).

\subsubsection{The significant attributes of management practices affecting construction productivity in the Indian construction industry}

The significant attributes of management practices affecting construction productivity in Indian construction industry are contractual disputes, availability of training and development for enhancing skills, conflict of interests

Tab. 2: Reliability analysis of the attributes selected for this study

\begin{tabular}{lc}
\hline Cronbach's alpha & No. of items \\
\hline 0.87 & 19 \\
\hline
\end{tabular}


Tab. 3: Relative importance index (RII) of attributes of management practice affecting construction productivity

\begin{tabular}{lllll}
\hline Rank & Total responses & Total score & RII & Attribute name \\
\hline 1 & 105 & 476 & 0.91 & Coordination between all stakeholders \\
2 & 105 & 470 & 0.90 & Ability to handle the crisis by the project managers \\
3 & 105 & 462 & 0.88 & Social skills of key team managers \\
4 & 105 & 458 & 0.87 & Timely payment of completed works \\
5 & 105 & 455 & 0.87 & Design capability and frequent design changes \\
6 & 105 & 442 & 0.84 & Contractual disputes \\
7 & 105 & 420 & 0.80 & Availability of training and development for enhancing skills \\
8 & 105 & 418 & 0.80 & Conflict of interests among team members \\
9 & 105 & 410 & 0.78 & Scope clarity of the project \\
10 & 105 & 387 & 0.74 & Exceptional difference between client and architect \\
\hline
\end{tabular}

among team members, scope clarity of the project and exceptional difference between client and architect having a rating on the RII of $0.84,0.80,0.80,0.78$ and 0.74 , respectively (Table 3 ). The contractual disputes and conflict of interest were the reason of failure for a number of projects as reported by world bank report and other researchers irrespective of the type of construction and the value of funds associated (Zouher Al-Sibaie et al. 2014; Jarkas et al. 2015).

\subsubsection{The least significant attributes of management practices affecting construction productivity in the Indian construction industry}

The least significant attributes of management practices affecting construction productivity in the Indian construction industry are customer/client satisfaction, willingness to adopt change and claim geniuses having a rating on the RII of $0.65,0.64$ and 0.62 , respectively (Table 3 ).

\section{Conclusion and discussion}

This study revealed that the minimum value of reliability analysis for all the attributes is above 0.62, i.e. all the attributes selected for this study had a significant impact on construction productivity of the building projects. This study highlighted and concluded that the management attributes are significant and could be managed and controlled by identifying the key issues and taking the initiative to resolve them. Nguyen and Chileshe (2015) concluded that the factors for the failure of any construction project could be avoided by timely identification of critical factors. Rezakhani (2012) also explained the main significant risk factors for the success of any construction project. The similar trait revealed in this article is the impact of management on the success and the productivity of construction projects was also reported by previous research articles in different demographic conditions (Svejvig and Andersen 2015; Gurmu and Aibinu 2017; ISO 31000 2009). The success of a project is depended on several attributes and it is possible to complete the project within the time frame and within the budget allocated to the project. It requires a dedicated management team, lead by a capable leader who could make the right decisions on time and delicate the authority to make decisions for the benefit of the project. One of the main attributes for the success of any project is the commitment of top management and the presence of the right culture at the management level. This research added the value to the existing knowledge bank by identifying and analysing the impact of management practices/techniques on the construction productivity of building construction projects. This study provided a solution to the construction managers and project managers to apply the findings of this study in their projects to control the issues of low productivity and delays in completion of the projects using the identified most significant attributes of management practices affecting construction productivity in the Indian construction industry. The scope of the current study was limited to the Indian building industry, and the analytical unit chosen to conduct research and collect data at the project/site level. Furthermore, the only building construction project has been selected for the present study.

\section{References}

Abdul Kadir, M. R., Lee, W. P., Jaafar, M. S., Sapuan, S. M., \& Ali, A. A. A. (2005). Factors affecting construction labour productivity for Malaysian residential projects. Structural Survey, 23(1), pp. 42-54.

Afifi, M., Al-Hussein, M., Abourizk, S., \& Fotouh, A. (2016). Discrete and continuous simulation approach to optimize the productivity of modular construction element. In: Proceedings of the International Symposium on Automation and Robotics in Construction (ISARC 2016), Vol. 33(1), pp. 1-6. 
Ajala, A. T., The Federal Polytechnic \& Traffic Management Strategies. (2017). Traffic Management Strategies and Best Practices. GG Associates, Abeokuta, Nigeria.

Alazzaz, F., \& Whyte, A. (2015). Linking employee empowerment with productivity in off-site construction. Engineering Construction and Architectural Management, 22(1), pp. 21-37.

Al-Tabtabai, H. C., Kartam, N., Flood, I., \& Alex, A. P. (1997). Construction project control using artificial neural networks. Artificial Intelligence for Engineering Design, Analysis and Manufacturing: AIEDAM, 11(1), pp. 45-57.

Alves, T., Milberg, C., \& Walsh, K. D. (2012). Exploring lean construction practice, research, \& education. Engineering Construction \& Architectural Management, 19(5), pp. 512-525.

Ameh, O., \& Osegbo, E. (2011). Study of relationship between time overrun and productivity on construction sites. International Journal of Construction Supply Chain Management, 1(1), pp. 56-67.

Ameh, S., Dania, A., Zubairu, I., \& Bustani, S. (2010). Sustainable construction education: assessing the adequacy of built environment professional's training. In: West Africa Built Environment Research (WABER Conference), Ghana, 27-28 July 201, pp. 27-28.

Assefa Tsehayae, A., Robinson Fayek, A., Tsehayae, A. A., \& Fayek, A. R. (2016). Developing and optimizing context-specific fuzzy inference system-based construction labor productivity models. Journal of Construction Engineering \& Management, 142(7), p. 04016017.

Aziz, R. F., \& Hafez, S. M. (2013). Applying lean thinking in construction and performance improvement. Alexandria Engineering Journal, 52(4), pp. 679-695.

Banawi, A., \& Bilec, M. M. (2014). A framework to improve construction processes: Integrating lean, green and six sigma. International Journal of Construction Management, 14(1), pp. 45-55.

Barlow, P. (2009). Cost of Quality in Construction Industry. California Polytechnic State University, San Luis Obispo.

Björnfot, A., \& Sardén, Y. (2006). Prefabrication a lean strategy for value generation in construction. In: Sacks, R., \& Bertelsen, S. (eds.), Proceeding of the 14th International Group for Lean Construction, Catholic University of Chile, School of Engineering, January, pp. 265-277.

Boyko, C. T., \& Cooper, R. (2011). Clarifying and re-conceptualising density. Progress in Planning, 76(1), pp. 1-61.

Burgess, T. F., Grimshaw, P., Huaccho Huatuco, L., \& Shaw, N. E. (2017). Mapping the operations and supply chain management field: A journal governance perspective. International Journal of Operations \& Production Management, 37(7), pp. 898-926.

Castellani, D., Piva, M., Schubert, T., \& Vivarelli, M. (2018). R\&D and productivity in the US and the EU: Sectoral specificities and differences in the crisis. Technological Forecasting and Social Change, 138(April), pp. 279-291.

Chalker, M., \& Loosemore, M. (2016). Trust and productivity in Australian construction projects: A subcontractor perspective. Engineering, Construction and Architectural Management, 23(2), pp. 192-210.

Chancellor, W., \& Abbott, M. (2015). The Australian construction industry: Is the shadow economy distorting productivity? Construction Management and Economics, 33(3), pp. 176-186.
Dixit, S. (2018). Analysing enabling factors affecting the on-site productivity in Indian construction industry. Periodica Polytechnica Architecture, 49(2), pp. 185-193.

Dixit, S. \& Sharma, K. (2019). A review of studies in structural health monitoring (SHM). In: Miroslaw, J. S., \& Miklos, H. (eds.), Budapest University of Technology and Economics \& Diamond Congress Ltd., Budapest, pp. 95-99. doi: https://doi. org/10.3311/CCC2019-013

Dixit, S., Mandal, S. N., Thanikal, J. V., \& Saurabh, K. (2018). Construction productivity and construction project performance in Indian construction projects. In: Creative Construction Conference 2018, CCC 2018, 30 June - 3 July 2018, Ljubljana, Slovenia, At Ljubljana, Slovenia, pp. 379-386.

Dixit, S., Mandal, S. N., Thanikal, J. V., \& Saurabh, K. (2019a). Evolution of studies in construction productivity: A systematic literature review (2006-2017). Ain Shams Engineering Journal., 10(3), pp. 555-564. doi: 10.1016/j.asej.2018.10.010

Dixit, S., Mandal, S. N., Thanikal, J. V., \& Saurabh, K. (2019b). Study of significant factors affecting construction productivity using relative importance index in Indian construction industry. E3S Web of Conferences, 140, 09010. doi: 10.1051/ e3sconf $/ 201914009010$

Dixit, S., Pandey, A. K., Mandal, S. N., \& Bansal, S. (2017). A study of enabling factors affecting construction productivity: Indian scenario. International Journal of Civil Engineering and Technology, 8(6), pp. 741-758.

Doloi, H., Sawhney, A., Iyer, K. C., \& Rentala, S. (2012). Analysing factors affecting delays in Indian construction projects. International Journal of Project Management, 30(4), pp. 479-489.

Fulford, R., \& Standing, C. (2014). Construction industry productivity and the potential for collaborative practice. International Journal of Project Management, 32(2), pp. 315-326.

Grau, D., Caldas, C. H., Haas, C. T., Goodrum, P. M., \& Gong, J. (2009). Impact of fast automated tracking of construction components on labor productivity. In: 26th International Symposium on Automation and Robotics in Construction (ISARC 2009), Austin, TX, USA, pp. 505-511.

Gurmu, A. T., \& Aibinu, A. A. (2017). Construction equipment management practices for improving labor productivity in multistory building construction projects. Journal of Construction Engineering and Management, 143(10), p. 04017081.

Hahn, M. H., Lee, K. C., \& Jo, N. Y. (2015). Scenario-based management of individual creativity. Computers in Human Behavior, 42, pp. 36-46.

Howell, C. A. (1999). What is lean construction. In: Proceedings of the Seventh Annual Conference of the International Group for Lean Construction IGLC-7, Berkeley, July 26-28, pp. 1-10.

Hughes, R., \& Thorpe, D. (2014). A review of enabling factors in construction industry productivity in an Australian environment. Construction Innovations, 14(2), pp. 210-228.

ISO 31000. (2009). ISO 31000:2009 risk management - Principles and guidelines. Risk Management, 31000, p. 24.

lyer, K. C., \& Jha, K. N. (2005). Factors affecting cost performance: Evidence from Indian construction projects. International Journal of Project Management, 23(4), pp. 283-295.

Jamil, A. H. A., \& Fathi, M. S. (2016). The integration of lean construction and sustainable construction: A stakeholder perspective in analyzing sustainable lean construction 
strategies in Malaysia. Procedia Computer Science, 100, pp. 634-643.

Jarkas, A. M., \& Bitar, C. G. (2012). Factors affecting construction labour productivity in Kuwait. Journal of Construction Engineering and Management, 138(July), pp. 811-820.

Jarkas, A. M., Al Balushi, R. A., \& Raveendranath, P. K. (2015). Determinants of construction labour productivity in Oman. International Journal of Construction Management, 15(4), pp. 332-344.

Jarkas, A. M., Kadri, C. Y., \& Younes, J. H. (2012). A survey of factors influencing the productivity of construction operatives in the state of Qatar. International Journal of Construction Management, 12(3), pp. 1-23.

Jiang, R., Wu, C., Mao, C., \& Shrestha, A. (2016). Ecosystem visualization and analysis of Chinese prefabricated housing industry. Procedia Engineering, 145, pp. 436-443.

Kaming, P. F., Olomolaiye, P. O., Holt, G. D., \& Harris, F. C. (1997). Factors influencing craftsmen's productivity in Indonesia. International Journal of Project Management, 15(1), pp. 21-30.

Khodeir, L. M., \& Othman, R. (2016). Examining the interaction between lean and sustainability principles in the management process of AEC industry. Ain Shams Engineering Journal, 9(4), 1627-1634.

Kishan, P. (2014). A study of risk factors affecting building construction projects. International Journal of Engineering Research and Technology, 3(12), pp. 831-835.

Kwon, S., Lee, G., Ahn, D., \& Park, H. (2014). A modified-AHP method of productivity analysis for deployment of innovative construction tools on construction site. Journal of Construction Engineering and Project Management, 4(1), pp. 45-50.

Lee, E.-B., Lee, H., \& Ibbs, C. W. (2007). Productivity aspects of urban freeway rehabilitation with accelerated construction. Journal of Construction Engineering and Management, 133(10), pp. 798-806.

Lim, E. C., \& Alum, J. (1995). Construction productivity: Issues encountered by contractors in Singapore. International Journal of Project Management, 13(1), pp. 51-58.

Ma, G., Gu, L., \& Li, N. (2015). Scenario based proactive robust optimization for critical chain project scheduling. Journal of Construction Engineering \& Management, 141(10), pp. 1-12.

Ma, L., \& Liu, C. (2014). Did the late-2000s financial crisis influence construction labour productivity? Construction Management and Economics, 32(10), pp. 1030-1047.

Ma, L., \& Liu, C. (2018). Decomposition of temporal changes in construction labour productivity. International Journal of Construction Management, 18(1), pp. 65-77.

Ma, L., Liu, C., \& Mills, A. (2016). Construction labor productivity convergence: A conditional frontier approach. Engineering, Construction and Architectural Management, 23(3), pp. 283-301.

Mahamid, I. (2013). Contractors perspective toward factors affecting labor productivity in building construction. Engineering, Construction and Architectural Management, 20(5), pp. 446-460.

Mani, N., Kisi, K. P., Rojas, E. M., \& Foster, E. T. (2017). Estimating construction labor productivity frontier: Pilot study. Journal of Construction Engineering and Management, 143(10), p. 04017077.
Molavi, J., \& Barral, D. L. (2016). A construction procurement method to achieve sustainability in modular construction. Procedia Engineering, 145, pp. 1362-1369.

Moselhi, O., \& Khan, Z. (2010). Analysis of labour productivity of formwork operations in building construction. Construction Innovations, 10(3), pp. 286-303.

Neelamkavil, J. (2009). Automation in the prefab and modular construction industry. In: International Symposium on Automation and Robotics in Construction ISARC 2009, Austin, TX, June 24-27, 2009, pp. 24-27.

Nguyen, T. P., \& Chileshe, N. (2015). Revisiting the construction project failure factors in Vietnam. Built Environment Project and Asset Management, 5(4), pp. 398-416.

Ocampo, L. A., \& Clark, E. E. (2015). A sustainable manufacturing strategy framework: The convergence of two fields. Asian Academy of Management Journal, 20(2), pp. 29-57.

Oglesby, C. H., Parker, H. W., \& Howell, G. A. (1989). Productivity improvement in construction. Journal of Construction Engineering and Management, 111. p. 1.

Ok, S. C., \& Sinha, S. K. (2006). Construction equipment productivity estimation using artificial neural network model. Construction Management and Economics, 24(10), pp. 1029-1044.

Poirier, E. A., Staub-French, S., \& Forgues, D. (2015). Measuring the impact of BIM on labor productivity in a small specialty contracting enterprise through action-research. Automation in Construction, 58, pp. 74-84.

Rezakhani, P. (2012). Classifying key risk factors in construction projects. Bulletin of the Polytechnic Institute of Jassy, Constructions. Architecture Section, 62(2), pp. 27-38.

Safa, M., Cardenas, J. G., Leblanc, D. G., Rose, D., \& Shahi, A. (2016). Improving construction labor productivity using automatic rebar tying gun. In: 33rd International Symposium on Automation and Robotics in Construction (ISARC 2016), Auburn, Alabama, USA, 18-21 July 2016, pp. 1-5.

Santosh, V., \& Apte, M. R. (2014). Productivity in building construction. Journal of Mechanical and Civil Engineering, 10(5), pp. 64-71.

Sezer, A. A., \& Bröchner, J. (2014). The construction productivity debate and the measurement of service qualities. Construction Management and Economics, 32(6), pp. 565-574.

Svejvig, P., \& Andersen, P. (2015). Rethinking project management: A structured literature review with a critical look at the brave new world. International Journal of Project Management, 33(2), pp. 278-290.

Sweis, G. J., Hiyassat, M., \& Al-Hroub, F. F. (2016). Assessing lean conformance by first-grade contractors in the Jordanian construction industry. Construction Innovation, 16(4), pp. 446-459.

Teizer, J., Cheng, T., \& Fang, Y. (2013). Location tracking and data visualization technology to advance construction ironworkers' education and training in safety and productivity. Automation in Construction, 35(July 2015), pp. 53-68.

Tsehayae, A. A., \& Fayek, A. R. (2016). System model for analysing construction labour productivity. Construction Innovations, 16(2), pp. 203-228.

Wang, X., Chen, Y., Liu, B., Shen, Y., \& Sun, H. (2013). A total factor productivity measure for the construction industry and analysis of its spatial difference: A case study in 
China. Construction Management and Economics, 31(10), pp. 1059-1071.

Xu, G., Li, M., Chen, C. H., \& Wei, Y. (2018). Cloud asset-enabled integrated loT platform for lean prefabricated construction. Automation in Construction, 93(September 2017), pp. 123-134.

Zhang, L., \& Chen, X. (2016). Role of lean tools in supporting knowledge creation and performance in lean construction. Procedia Engineering, 145, pp. 1267-1274.
Zhang, L., \& Fan, W. (2013). Improving performance of construction projects. Engineering, Construction and Architectural Management, 20(2), pp. 195-207.

Zouher Al-Sibaie, E., Mohammed Alashwal, A., Abdul-Rahman, H., \& Kalsum Zolkafli, U. (2014). Determining the relationship between conflict factors and performance of international construction projects. Engineering, Construction and Architectural Management, 21(4), pp. 369-382. 